\title{
Pembinaan Iman Kristen untuk Pekerja Indonesia di Ladang Sawit Sitiawan, Perak
}

\author{
Joni Manumpak Parulian Gultom ${ }^{1 *}$, Hendri Hutapea ${ }^{2}$, Rikardo Butar-Butar ${ }^{3}$, Eko \\ Prasetyo $^{4}$ \\ 1, 4, Prodi Teologi, STT Real Batam \\ ${ }^{2,3}$ Prodi PAK, STT Real Batam \\ *jonimanumpakgultom@gmail.com
}

\begin{abstract}
The faith mature of believers is the duty of church leaders also of all who have received salvation in Christ Jesus. It is also an urgent concern and needs facing by Indonesian male workers working in Malaysian palm oil fields. The people who need help and assistance spiritually to be accompanied and taught about the basic principles of God's Word. It is difficult faced because of the many obstacles and obstacles faced in being able to go to worship and serve God. The reason is, the local church is limited. They do something for them is not maximize. It is because constrained by the existing language and culture. How is the matter STT REAL can provide a little solution in building their faith and spiritual life? And what kind of strategies can be maximized to do for them? By using descriptive qualitative research methods, it is obtaining how the values and data are accurate directly. The purpose of this research is to make a positive contribution to building the Indonesian Christian community, especially those who are working in Malaysia that they remain in the faith and continue to experience good spiritual growth.

Keywords: Keywords: Development, Faith, Christian Workers, Spiritual growth, Sitiawan
\end{abstract}

Abstrak

Pembinaan iman orang percaya bukan saja menjadi tugas dari para pemimpin gereja namun juga semua orang yang telah menerima keselamatan dalam Kristus Yesus. Hal ini jugalah yang menjadi perhatian dan kebutuhan yang urgen dihadapi oleh para pekerja pria Indonesia yang bekerja di lading lading sawit Malaysia. Mereka adalah orang yang memerlukan bantuan dan pertolongan khususnya secara rohani untuk didampingi dan diajarkan tentang prisn dasar Firman Tuhan. Hal ini menjadi kesulitan yang dihadapi karena banyaknya halangan dan hambatan yang dihadapi untuk bisa pergi beribadah dan melayani Tuhan. Alasan lainnya adalah bagaimana gereja lokal sangat terbatas sekali dapat melayani mereka karena terkendala dengan Bahasa dan budaya yang ada. Pertanyaannya adalah bagaimana STT REAL memberikan sedikit solusi dalam membina iman dan kehidupan rohani mereka? Dan strategi srategi seperti apa yang bisa dimaksimalkan untuk dikerjakan buat mereka? Dengan menggunakan metode penelitian desktiptif secara kualitatif didapatkan bagaimana nilai dan data data akurat secara langsung. Tujuan dari penelitian ini adalah untuk memberikan kontribusi positif untuk membangun masyarakat Kristen Indonesia khususnya yang sedang bekerja di Malaysia sehingga tetap bertahan dalam iman dan terus mengalami pertumbuhan kerohanian yang baik.

Kata kunci: Pembinaan, Iman, Pekerja Kristen, pertumbuhan Rohani, Sitiawan

\section{PENDAHULUAN}

Tenaga Kerja Indonesia yang berada di Malaysia tersebar ke berbagai tempat yang menyebar di seluruh negeri, termasuk juga di daerah Sitiawan, Negeri Perak. Selain dari manufaktur dan elektronik, tenaga kerja Indonesia terserap di perkebunan - perkebunan sawit. Letak perkebunan sawit sendiri berada di daerah pedalaman yang jauh dari kota dan penduduk. Mereka yang bekerja di sana berada dalam tempat tempat penampungan yang semi permanen dan beraktifitas di sekitar ladang. Semua pekerja yang ada berjenis kelamin laki laki. Mereka bersal dari banyak tempat di Indonesia seperti Aceh, Jawa dan tidak sedikit juga dari Nusa Tenggara Timur yang mayoritas beragama Katolik dan Protestan.

Jumlah mereka terbilang cukup banyak dengan rata rata umur beragam antara 17 sampai 50 tahun. Banyak dari mereka tidak pernah masuk dalam bangku sekolah dasar dan hanya ada dalam beberapa hitungan jari saja yang pernah menyelesaikan sekolah dasar. Hal lainnya yang perlu dicermati adalah tingkat kerohanian mereka yang buta tentang kekristenan. Meskipun mereka dari 
lahir sudah Kristen atau Katolik namun nilai nilai kekristenan itu tidak mendalam masuk dalam hati mereka. Hal ini disebabkan oleh banyak faktor. Selain dari tingkat pendidikan yang rendah, kemampuan ekonomi mereka juga sangat lemah. Ini yang membuat mereka tidak terlalu tertarik dengan pertemuan pertemuan ibadah dikarenakan hal hal untuk menambah penghasilan. Hal budaya dan tradisi juga menjadi penghalang yang cukup besar untuk mereka secara aktif mengambil bagian dalam pertumbuhan iman.

Setelah mereka merantau ke negeri jiran Malaysia untuk bekerja di ladang sawit khususnya, kebiasaan dan tradisi budaya itu tetap menjadi ikatan dalam kehidupan sehari hari. Hingga waktu terus berganti, tingkat pertumbuhan iman mereka juga tidak pernah berubah. Kehidupan doa, pembacaan Firman Tuhan menjadi hal yang sangat tidak lazim untuk dilakukan sebagai gaya hidup orang percaya. Kekudusan hidup dan karakter Kristus hampir tidak dapat kita kenali dari kehidupan mereka. Gaya hidup free sex, minuman keras, judi, obat obat terlarang dan beberapa kasus pencurian dan perkelahian sering terjadi dalam komunitas mereka dan juga di area sekitar tempat tingal mereka.

Gereja yang jauh dari lingkungan tempat tinggal mereka menjadi kendala lainnya. Walaupun mereka sudah memantapkan diri untuk hadir dalam Ibadah Minggu khususnya namun mereka tidak dapat dilayani dengan maksimal dikarenakan hampir di semua gereja yang mereka datangi tidak bisa berbahasa Indonesia dengan lancar. Gereja gereja di Malaysia sangat jarang menggunakan Bahasa Melayu sebagai Bahasa penghantar kotbah. Hampir tidak ada pendeta atau hamba Tuhan yang bisa datang untuk memberi siraman rohani ke lingkungan tempat tinggal mereka dalam jangka waktu lama.

Dari kesemuanya hal yang di atas bagaimana cara dan langkah strategis yang dilakukan oleh STT REAL untuk dapat ambil bagian dalam pembinaan iman pekerja pria Indonesia yang berada di ladang ladang Sawit Sitiawan untuk tetap terpelihara iman dan kasih mereka kepada Tuhan, mengalami pertumbuhan rohani dan kehidupan yang lebih baik di Malaysia. Lewat pengabdian kepada komunitas pekerja Kristen Indonesia di Stiawan diharapkan mereka menjadi pekerja pekerja yang lebih bijaksana dan bertumbuh dalam iman. Sehingga tidak menjadi sumber kekacauan atau hal hal buruk di daerah tempat tinggal mereka.

\section{METODE}

Jurnal ini disusun dengan menggunakan metode deskriptif dengan pendekatan kualitatif. Peneliti melihat dan mengumpulkan data sebanyak banyaknya dengan melihat hal hal actual yang nampak, melakukan pencatatan dan tingkah laku masyarakat yang diteliti ${ }^{1}$ sehingga peneliti dapat melihat dan memahami komunitas masyarakat secara detail, pribadi dan personal dan dapat mengungkapkan apa yang menjadi dasar prinsip dan konsep hidupnya. Hal ini penting untuk memberikan pandangan yang lebih baik dan sempurna memungkinkan kita memahami masyarakatnya secara personal dan memandang mereka sebagaimana mereka sendiri mengungkapkan pandangan dunianya. Hasil yang diperoleh memungkinkan kita membuat dan menyusun konsep-konsep yang hakiki². Ada beberapa kriteria metode ini digunakan karena 1) data lapangan pada kondisi natural, langsung menemukan data ke sumber aslinya, 2) Tidak menekankan kepada angka namun gambar dan komunikasi verbal, 3) Data yang diperoleh dari lingkup itu sendiri ini akan memberik waktu waktu yang telah ditentukan. Waktu yang paling tepat adalah sore hari ke malam setelah mereka pulang dari pekerjaan.

Dengan dukungan penuh dari institusi STT REAL, maka dosen dosen mengatur waktu yang tepat dengan pengkondisian lapangan. Hal ini diperlukan karena faktor faktor jarak yang melewati batas negara dan juga faktor keamananan yang harus masuk ke dalam area perhutanan dan jauh dari pemukiman penduduk. Hal lainnya yang diperhatikan adalah transportasi, dikarenakan peraturan peraturan yang melarang kendaran dari luar untuk bisa masuk ke dalam area penelitian dengan leluasa.

\footnotetext{
${ }^{1}$ Andi Tenri Sanna Ilma, "Bahan Ajar: Metodologi Riset" (2014).

${ }^{2}$ I. M. Wirarta, Metodologi Penelitian Sosial Ekonomi, Andi Offset, 2006.
} 
Persiapan persiapan pertemuan rohani seperti kelas kelas Alkitab sederhana dan pembacaan Firman Tuhan serta motivasi dan kekuatan iman menjadi materi khusus yang dipersipakan secara mendalam. Diharapakan kedatangan Dosen STT REAL memberi dampak positif untuk pertumbuhan iman pekerja Indonesia di lading sawit Sitiawan ini.

Pembinaan iman pekerja pria Indonesia di ladang ladang sawit Sitiawan, Perak Malaysia ini dilaksanakan secara bertahap dari tanggal 7 Januari s/d 7 Februari 2019. Untuk kesuksesan berjalannya penelitian ini maka peneliti menggandeng beberapa pembina gereja lokal yang ada di Ipoh dan Sitiawan serta jemaat lokal Malaysia untuk membantu dalam hal prosedur keamanan, transportasi, ijin untuk berkunjung dan lain lain. Diharapkan kegiatan pembinaan iman yang juga menjadi penelitian ini dapat memberikan manfaat yang besar dalam kehidupan rohani, identitas iman Kristen yang kuat serta pertumbuhan iman di kalangan pekerja Indonesia Kristen yang dikunjungi. Sehingga lewat kegiatan ini menjadi sebuah jalan untuk pengabdian kepada masyarakat Kristen Indonesia yang sedang bekerja di Malaysia dapat terus dilanjutkan dan dikembangkan ke kota kota lain oleh Institusi STT REAL Batam.

\section{HASIL DAN PEMBAHASAN \\ Pembinaan Iman lewat sharing Firman Tuhan}

Metode awal yang paling tepat guna untuk pekerja Kristen di Sitiawan ini adalah mengumpulkan mereka beribadah dan mendengarkan Firman Tuhan di hari Sabtu malam atau Minggu malam. Waktu yang diberikan disesuaikan dengan keadaan lokasi yang tidak selalu bisa mengadakan Ibadah Minggu. Firman Tuhan tetap menjadi kekuatan pertumbuhan iman yang paling utama (Roma 1 :16-17, Roma 10:17). Firman Tuhan yang terus menerus diperdengarkan dan dikotbahkan untuk jemaat menjadi kekuatan rohani untuk tetap berjalan dalam kebenaran. Ada beberapa alasan mengapa banyak orang tidak suka dengan mendengarkan Firman Tuhan. Hal yang paling utama adalah dosa dan kenikmatan dunia. Dalam pekerjaan dan lingkungan yang sangat jauh dari pemukiman penduduk dan rasa bosan yang ada seringkali membuat para pekerja ini kehilangan arah dan tujuan hidup yang benar. Mereka seringkali mencari cara yang tidak sesuai dengan kebenaran untuk bisa merasa bahagia. Kesulitan kesulitan hidup di negeri jiran dengan tanggung jawab pekerjaan yang besar serta gaji yang relative kecil membuat kehidupan mereka sering mengali tekanan yang kuat. Belum lagu diperparah dengan tingkat pendidikan yang rendah seringkali mmebuat mereka tidak punya jalan keluar untuk berpikir jernih melihat masa depan. Kadangkala budaya dan tradisi dari kampong yang negative sering mereka praktekkan di lingkungan kehidupan mereka di Malaysia.

Oleh sebab itu Firman Tuhan yang disampaikan harus dapat menjawab kebutuhan dasar mereka tentang kehidupan. Teori Maslow mengemukakan tentang piramida kehidupan. Dari piramida itu bisa di kerucutkan lagi kebutuhan apa yang secara rohani untuk diperdengarkan sehingga mereka mampu menjawab dan menghadapi proses kehidupan dalam iman. Ternyata bisa disimpulkan bahwa teori ini menjadikan kebutuhan hidup adalah hal yang paling diutamakan secara jasmani atau fisik namun ada empat bagian hal lainnya tidak menunjuk kepada jasmani namun hal hal batiniah ${ }^{3}$. Hal hal itu adalah seperti 1) kebutuhan akan rasa aman, 2) Kebutuhan akan rasa cinta atau dimiliki, 3) Kebutuhan akan rasa dipercayai atau dihargai dan terakhir 4) Kebutuhan untuk menyatakan diri (aktualisasi diri).

Firman yang dibagikan dalam sharing harus secara lugas dan tegas dapat memberi jalan keluar atau membangunkan iman jemaat pekerja Indonesia ini. Semua poin yang dia atas sebenarnya adalah menjadi tema sentral yang bisa di berikan kepada umat Kristen pada umumnya. Namun dengan melihat dan berinteraksi secara langsung dengan mereka maka tema yang kuat untuk di bagikan adalah tentnag kebutuhan untuk rasa aman dan dicintai atau di miliki. Menagapa demikian, karena seperti para pekerja Indonesia di ladang sawit Malaysia seringkali menghadapi tantangan keselamatan dan juga ancaman ancaman yang ada. Rasa kekuatiran yang lebih ada dalam hidup mereka. Poin lainnya adalah tentang dicintai atau dimiliki. Mereka adalah orang orang sederhana yang termarginalkan

\footnotetext{
${ }^{3}$ Subaidi Siti Muazaroh, "Kebutuhan Manusia Dalam Pemikiran Abraham Maslow," Al-Mazahib 7, no.
} 1 (2019): 17-33 
hampir di seluruh aspek kehidupan manusia. Firman itu menjadi jalan keluar bahwa Tuhan Yesus menjadi pribadi yang tidak pernah meniggalkan mereka dan mau menyelamatkan mereka ${ }^{4}$. Pendekatan kasih dan pengampuanan serta menerima apa adanya bisa menjadi acuan awal untuk dijelaskan kepa mereka.

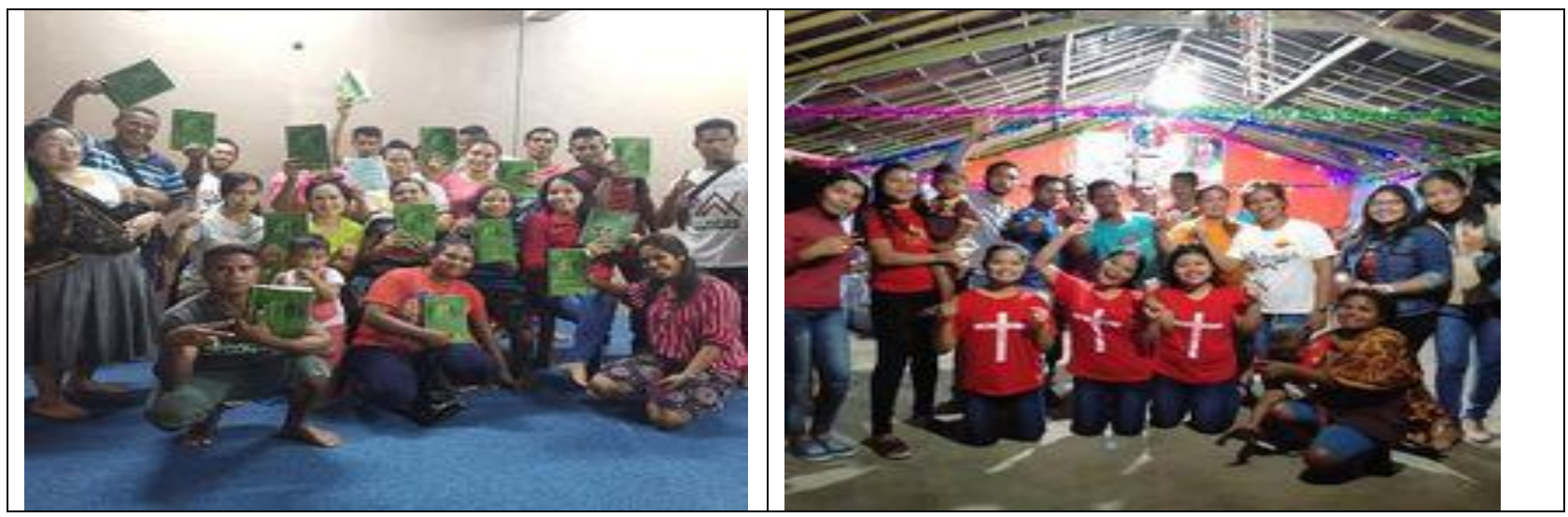

Gambar 1. Foto Pembinaan Iman Melalui Kelas dan Melalui Family Gathering

\section{Kebersamaan Dalam Kasih (Fellowship)}

Dosen dosen yang bergerak harus juga bisa menjadi manager dan juga eksekutor yang baik untuk mengadakan acara acara rohani spesial. Acara acara ini sangat berpengaruh sekali untuk memerikan kepada mereka kesempatan aktualisasi diri, mengambil beban untuk pelayanan. Acara yang di ambil bisa bersamaan dengan perayaan hari besar seperti Natal dan Paskah. Disini dosen bertindak seperti pelayan Tuhan yang bekerja sama dengan para pengurus gereja lokal yang diikutkan untuk dapat menyelesaikan acara ini dengan baik. Strateginya adalah dengan melibatkan mereka didalam acara ini secara lengkap. Dari ketua panitia sampai kepada seksi seksi pendukung untuk memperlancar kelangsungan acara. Sebagai manager yang baik maka dosen sebagai pembimbing iman, memberia arahan rohani dalam rapat rapat yang diadakan dengan menekankan kebersamaan, kekeluargaan dan juga kerendahan hati untuk saling bergantung.

Tidak dipungkiri akan terjadi ketegangan atau perselisihan di dalam persiapan acara ini. Namun hal ini menjadi cara yang baik untuk menyatukan hati supaya unity seperti Firman Tuhan. Karakter karakter ilahi mulai ditanamkan dalam kegiatan ini, seperti kesabaran dalam mencari dana, ketekunan dalam doa syaafaat dan berjaga jaga, kerendahan hati untuk saling menguatkan dan meneguhkan diantara sesama anggota tim sampai karakter hati hamba bahwa acara ini hanya untuk kemuliaan Nama Tuhan.Para dosen di sini bertindak seperti pemimpin rohani yang menjadi sumber inspirasi dan hikmat buat tim yang ada. Pada akhirnya lewat kebersamaan atau fellowship ini sosialisasi dan komunikasi terjalin makin akrab dan mendalam. Kebenaran Firman Tuhan dipraktekkan secara langsung dengan tugas dan tanggung jawab yang mereka milik. Kualitas pelayanan pun sudah mulai di ajari pelan pelan sehingga dapat maksimal dalam kesempatan yang ada sehingga dapat menghalang keinginan untuk melakaukan dosa dan keinginan daging.

${ }^{4}$ Ratnah Rahman, S Sos, and M Si, "Peran Agama Dalam Masyarakat Marginal," Sosioreligius 4, no. 1 (2019): 80-89. 


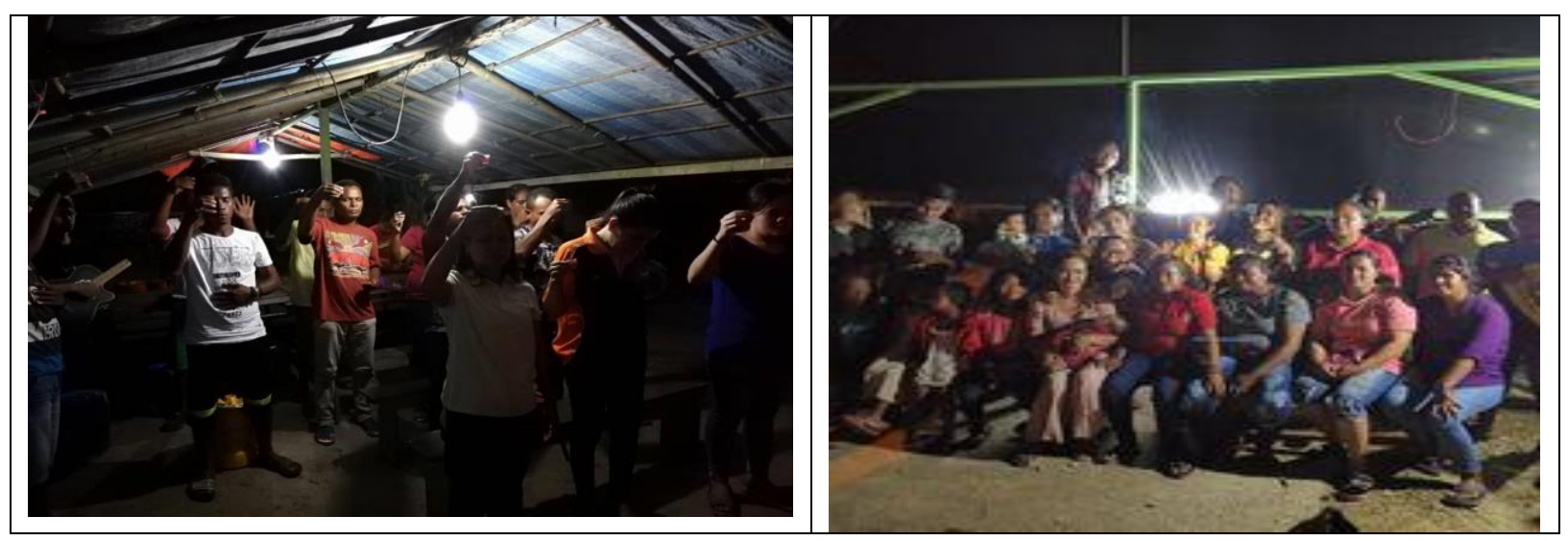

Gambar 2. Foto Pembinaan Iman Melalui Ibadah Minggu

\section{Pembinaan Iman melalui kelas kelas bible study}

Hal lainnya adalah dengan membuka kelas kelas Bible Study sebagai bagian dari pembinaan iman jangka panjang. Waktu yang sangat singkat ini dapat digunakan untuk membangun segi kognitif para tenaga kerja Indoensia ini untuk melek Alkitab. Hal ini menjadi sangat penting untuk persiapan mereka saat pulang nanti ke Indonesia sudah bisa menjaga kerohanian mereka dengan baik. Dalam kelas ini selali memberikan pengertian tentang pengertian pengertian dasar Alkitab juga menjadi media yang baik untuk komunikasi dua arah terjalin. Dimana Dosen menjadi pengajar dan mereka menjadi murid muridnya. Pendekatan yang terjadi secara individu dalam ruang kelas dengan interaksi yang terjadi dapat memberi kesan kedekatan, keramahan dan keterbukaan.

Meskipun Dosen adalah seorang pengajar yang sangat dihormati dalam kelas perkuliahan namun fungsi ini bisa disesuaikan menjadi seorang Guru Injil buat jemaat Tuhan para pekerja Kristen. Seperti layaknya guru Injil, tugas pokok nya adalah mengajar mereka untuk menjadi pribadi pribadi yang mengalami pertumbuhan rohani secara baik dalam nilai nilai dasar kekristenan yang sangat penting sepeti keselamatan dan kekudusan hidup. Hal ini menjadi sasaran utama dalam kelas pemuridan yang ada $^{5}$.

Penghalang dari keberadaan kelas ini adalah memang tingkat pendidikan para tenaga kerja ini sangat rendah. Tidak semua dari mereka yang bisa menulis dan membaca. Oleh sebab itu diperlukan strategi khusus untuk dapat memaksimalkan kelas yang ada. Bisa dengan mengulang gulang poin yang penting untuk supaya diingat. Atau dengan teknik repetisi bersama-sama. Bukan saja sebagai bentunk untuk mengingat namun juga memberi penekanan tersendiri bahwa itu adalah hal yang sangat penting. Hal ini pernah menjadi strategi yang sangat efektif pada zaman Para Rasul dengan mengajarkan hal itu berulang ulang kepada jemaat yang lain.

\section{SIMPULAN}

Kegiatan pembinaan Iman di lokasi ladang sawit Sitiawan, Perak telh dilakukan dengan baik oleh para dosen STT REAL sebagai tujuan dari program pengabdian kepada masyarakat Indonesia yang sedang bereja di Malaysia. Dari kegiatan ini didapatkan hasiol yang cukup positif dalam membina dan membangun iman para pekerja Indonesia sehingga menjadi lebih baik, berkarakter seperti apa yang menjadi kebenaraan Firman Tuhan. Ada beberapa kesimpulan dari kegiatan PKM ini, 1) Setiap pribadi yang telah diselamatkan oleh Kristus mempunyai tanggung jawab tinggi untuk dapat menyaksikan Firman Tuhan dimanapaun dan kapanpun serta bagaiamanapun keadaannya, 2) Para pekerja Kristen adalah pribadi pribadi yang bisa mengalami pertumbuhan iman dan perubahan dalam gaya hidup sehari harimenjadi jauh lebih positif dan menyenangkan. 3) Para pekerja Kristen dapat menjadi pelayan pelayan Tuhan yang saling melengkapi untuk dapat terus membangun persekutuan dengan Tuhan meskipun berada dalam ruang lingkup yang sederhana dan jauh dari pemukiman penduduk. 4)

${ }^{5}$ Jossapat Hendra Prijanto, "Panggilan Sebagai Guru Kristen Wujud Amanat Agung Yesus Kristus Dalam Penanaman Nilai Alkitabiah Pada Era Digital [A Christian Teacher's Calling in Response to Jesus Christ's Great Commission in Instilling Biblical Values in a Digital Era]," Polyglot: Jurnal Ilmiah 13, no. 2 (2017): 13. 
Dosen dapat menjadi Guru Injil juga yang efektif dalam mengajarkan nilai nilai dasar kekristenan kepada para tenaga kerja Kristen untuk mempersiapkan mereka dalam jangka panjang kualitas keimanan mereka menjadi jauh lebih baik saat pulang kembali ke Indonesia.

\section{DAFTAR PUSTAKA}

Ilma, Andi Tenri Sanna. "Bahan Ajar: Metodologi Riset" (2014).

Prijanto, Jossapat Hendra. "Panggilan Sebagai Guru Kristen Wujud Amanat Agung Yesus Kristus Dalam Penanaman Nilai Alkitabiah Pada Era Digital [A Christian Teacher's Calling in Response to Jesus Christ's Great Commission in Instilling Biblical Values in a Digital Era]." Polyglot: Jurnal Ilmiah 13, no. 2 (2017): 13.

Rahman, Ratnah, S Sos, and M Si. "Peran Agama Dalam Masyarakat Marginal." Sosioreligius 4, no. 1 (2019): 80-89.

Siti Muazaroh, Subaidi. "Kebutuhan Manusia Dalam Pemikiran Abraham Maslow.” Al-Mazahib 7, no. 1 (2019): 17-33.

Wirarta, I. M. Metodologi Penelitian Sosial Ekonomi. Andi Offset, 2006. 